\title{
ASSESSMENT OF ENERGY USE AND ELIMINATION OF CO2 EMISSIONS IN THE LIFE CYCLE OF AN OFFSHORE WIND POWER PLANT FARM
}

\author{
A. Tomporowski ${ }^{1)}$ \\ J. Flizikowski ${ }^{1)}$ \\ M. Opielak ${ }^{2)}$ \\ R. Kasner ${ }^{1)}$ \\ W. Kruszelnicka ${ }^{1}$ \\ 1) University of Science and Technology, Faculty of Mechanical Engineering, Poland \\ ${ }^{2)}$ Lublin University of Technology, Faculty of Mechanical Engineering, Poland
}

\begin{abstract}
Power stations in marine locations cause multi-faceted impact on the environment, man and the economy. There are not many studies devoted to modeling energy benefits for $\mathrm{CO}_{2}$ emissions. The paper presents the issues of assessing the efficiency of offshore wind farms, defined as the ratio of benefits to life cycle inputs. The scientific goal was to develop a mathematical model for efficiency in the design, manufacture, use and management of offshore wind power. The papers practical purpose is the experimental designation of the impact of selected post-use management methods, time of use and maritime location, i.e. average annual productivity of wind power plants on the efficiency of energy benefits from greenhouse gas emissions. The mathematical model of the integrated cost-benefit ratio has been developed for energy use assessment, taking into account the benefits generated by electricity production and the life-cycle $\mathrm{CO}_{2}$ emissions based on the LCA analysis using the CML method. Mathematical model validation was performed by determining the value of the indicator for an existing $2 \mathrm{MW}$ offshore wind farm and comparatively for fossil fuel production: lignite, stone, fuel oil and natural gas. Analytical and research work carried out showed that the higher the efficiency index, the higher the value of the indicator. It has been shown that the location of the power station at sea produces more favorable $\mathrm{CO}_{2}$ elimination rates, due to higher productivity compared to in-land wind power plants. A more favorable form of post-consumer management for $\mathrm{CO}_{2}$ has been determined as recycling. It was found that for electricity generated from offshore wind farms, the value of the energy efficiency benefit from $\mathrm{CO}_{2}$ emissions is higher than for fossil fuel energy production.
\end{abstract}

Keywords: energy efficiency, use of machines, offshore wind power plant farms, $\mathrm{CO}_{2}$ emissions

\section{INTRODUCTION}

Efficiency is the goal, the postulated state of the technological energy, allowing estimation, optimization, modernization, innovation: ideas, constructions and processes: generation, use, power and decommissioning, by comparing the benefits and expenditures in their life cycle.

For the purposes of this paper, the benefits of offshore wind power $(\mathrm{EW})$ include, inter alia, a product of power and energy, financial revenues, reduction of emissions to the marine environment, diversification of energy sources, development and activation of the environment, and other potential benefits which cannot be determined today $[2,11$, $13,17,24]$.

On the other hand, the costs of the operation included damage to the marine environment, energy consumed throughout the life cycle, incurred financial expenditures, harmful social outlays and potential costs that are currently unknown $[10,11,34]$.

The benefits and costs of action are divided into rational and irrational, measurable and immeasurable, actual and potential. Such comparisons can be made in many ways, but 
it is important to create a model that enables the analysis, evaluation and development of energy efficiency using expenditure and emissions throughout the life cycle $[10,11$, $17,18]$. From the literature analysis of the subject comes the conclusion that there are no studies on the modeling of energy benefits from the emission of harmful gases as an outlay for obtaining these benefits $[6,10]$.

In light of the above findings, the objectives of the study were:

1. To develop a mathematical model of the cost-effectiveness of the outlay for the design, manufacture, use, and disposal of offshore wind power (EW) power plants;

2. Experimental determination of the influence of selected management methods, use time and maritime location, i.e. average annual productivity of wind power plants influence on energy efficiency benefits from greenhouse gas emissions.

Problems: In order to achieve the objectives of the study, it was proposed to formulate the following research problems: 1. Taking into account such variables as: design, manufacturing, use and management, is it possible to develop an adequate mathematical model of energy efficiency (energy production) from $\mathrm{CO}_{2}$ emissions for the analysis, evaluation and development of marine EW?

2. What are the effects on the energy production efficiency from $\mathrm{CO}_{2}$ emissions for $\mathrm{EW}$ offshore wind farms coming from:

- power uses,

- expenditures (emissions) during the design, manufacture, use and development of offshore EW potentials,

- ways of utilizing post-use offshore EW potentials,

- usage time of offshore EW,

- maritime location, i.e. average annual productivity of offshore EW.

\section{MATHEMATICAL MODEL}

General assumptions: the basis for developing the mathematical model of energy efficiency of offshore EW for the purposes of design, manufacture, use and management were the assumptions of the general equation of development. The equation of the development of the renewable energy source efficiency according to the benefits and expenditures of energy, economy and ecology is [5-11, 17, 18, 29-34]:

$$
L(H, E, R, \Theta, t)=P\left(s, z, \Theta, t-t_{0}\right),
$$

where:

$H$ - performance characteristics as output quantities (efficiency, process harmlessness, power and electricity quality, $\mathrm{CO}_{2}$ emissions),

$E$ - features of internal components: energy conversion units,
$R$ - relations, interconnections of elements (the relations of elements of offshore (EW) wind power plants, materials, plastics, air, emissions, impact on operator health, system functionality, environment and accompanying devices);

$\Theta, t-t_{0}$ - time,

$s \quad$ - control, interference: design, manufacture, use, storage, recycling of EW off-shore material potential,

$z$ - interference.

The left side of the equation (1) (model) describes the properties of the processing process, its physical characteristics, specific to the class of activity. These properties depend on the elements $E_{1}, \ldots, E_{m}$, relationships (relations) between these elements $R_{1}, \ldots, R_{n}$ and are functions $\Theta$ and $t$ (time of operation and dynamic process). The unknowns are the elements of the set characteristics of the inputs processes for the preparation of elements for use of offshore EW in accordance with the conditions and purpose, development and the advantages of the use of energy $H$ as the response variables, which determine the effectiveness evaluation lack of uniformity and inefficiency, the variable efficiency, unwarranted consumption and nature power, internal energy consumption, construction and operating materials etc.

The right side of the equation (1) is a description of internal and external interference. They may depend on: the developmental form of the interaction, the control by the signals from the $s$ set (storage, recycling), interactive interaction, interaction of elements (material, machine, conversion process, conditions, marine environment, construction, ...), tensile-tension impact (associated with potential difference), which is the cause of compensatory processes; It may also occur as a disturbance of the system as expressed by $z$.

Taking into account the specific characteristics of the $U$ benefits and the outlays $N$ of using and operating wind turbines, equation (1) takes the form:

$$
L(E, R, U, N, \Theta, t)=P\left(s, z, \Theta, t-t_{0}\right) .
$$

Starting from the descriptive definition of efficiency, the formal form of the indicator can be given as the quotient of the utility $U(t)$ to the directly incurred expenditure $N(t)$ related to the time of action $[17,29]$ :

$$
E(t)=\frac{U(t)}{N(t)}
$$

The values of $U(t)$ and $N(t)$ denote the values of the obtained positive and negative flows - the expenditures spent up to the time $t$ from the beginning of the operation $(t=0)$.

The function $N(t)$ in time interval $(0, t)$ is a non-temporal function, i.e. in every elementary interval ( $\Delta t$ or $d t$ ) elementary value of inputs [17, 24]: 


$$
n(t)=\frac{d N(t)}{d t}
$$

is not less than zero, and the value of the function $N(t)$, depending on whether the function $n(t)$ is continuous or discrete, is determined from the relation:

$$
\begin{gathered}
N(t)=\int_{o}^{t} n(\tau) d \tau, \\
N(t)=\sum_{i}^{T} n i \cdot \Delta t_{i} .
\end{gathered}
$$

The use function of offshore wind power plants $U(t)$ in the given time interval can take both positive and negative values and its values based on the values of the elementary functions

$$
u(t)=\frac{d U(t)}{d t}
$$

depending on its form (continuous or discrete), was determined from the dependence:

$$
\begin{aligned}
& U(t)=\int_{0}^{t} u(\tau) d \tau, \\
& U(t)=\sum_{i}^{T} u_{1} \cdot \Delta t_{i} .
\end{aligned}
$$

In this consideration, the term "outlay" was defined as part of an engineering resource, i.e. energy-material-informationtime, spent in a given activity $[1,3,10,13-18]$. This can be expressed in different components in different units $[26,31]$.

The useful effect of off-shore wind power is interpreted as the part of the effect (effect, product) of the activity which has utility adequateness and which is the target of action, and the side effects of the action and its effects are subject to considerations of destructiveness $[6,18,29]$.

It has been assumed that the time interval $\Delta t$, in which the operation of the test object and analysis is considered, tends to zero. The momentary efficiency of the energy system is therefore the limit value of the change in effect $\Delta t$ by the increment of inputs $\Delta N$ in the time interval $\Delta t$ when $\Delta t$ tends to zero, in the form:

$$
E(t)=\lim _{\Delta t \rightarrow 0} \frac{U(t+\Delta t)-U(t)}{N(t+\Delta t)-N(t)}
$$

assuming that the interval is large enough, i.e.

$$
\Delta t=T \gg 0
$$

then the equation of instantaneous energy efficiency takes the form:

$$
E(t)=\frac{U(t+T)-U(T)}{N(t+T)-N(T)}=\frac{\Delta U}{\Delta N}=\frac{U(T)}{N(T)} .
$$

Utilization quotient of the benefits $U(\mathrm{~T})$ achieved in finite time interval $T$ by $N(\mathrm{~T})$ expenditure incurred at this time is the mean efficiency.

Assumptions of analysis, evaluation and development: Efficiency in the construction and operation of energy machinery is a feature that expresses the rational ability of systems to meet specific needs, desires for human well-being, their functionality, product quality, product harmony and the process of action (attainment of intended goals, according to purpose and requirements).

For the evaluation of production, operation and decommissioning of offshore wind farms in the life cycle the integrated indicator of the efficiency benefits incurred from the creation to elimination i.e. renewable energy source, has been defined in the form:

$$
E(t)=\frac{U(t)}{N(t)^{\prime}}
$$

where:

$E(t)$ - integrated life cycle efficiency indicator,

$U(t)$ - benefits in the life cycle,

$N(t)$ - outlays in the life cycle,

$t$ - time of use.

Denoting by:

$U_{i}$ - benefits in the time of the i-th year of use,

$m_{W}$ - outlays at the manufacturing stage,

$N_{i}$ - outlays in the time of the i-th year of use,

$m_{z}$ - outlays in the post use management,

can be written as [10]:

$$
E(t)=\frac{U(t)}{N(t)}=\frac{\sum_{i=1}^{t} U_{i}}{m_{W}+\sum_{i=1}^{t} N_{i}+m_{Z}} .
$$

For the considered offshore wind power plant, it is assumed that $m_{W}$ and $m_{Z}$ are constants, whereas $U_{i}$ and $N_{i}$ are random values. It is also assumed that $U_{1}, U_{2}, \ldots$ have the same distribution, and $N_{1}, N_{2}, \ldots$ have the same distribution, and that $U_{1}, U_{2}, \ldots$ are independent, and $N_{1}, N_{2}, \ldots$ are independent. For the purposes of the analysis, the assumption is that both $U_{1}$ and $N_{1}$ have normal distributions with known mean and variances. So:

$$
\begin{aligned}
U_{1}, U_{2}, \ldots \sim \mathcal{N}(\mu, \sigma) \text { independent, } \\
N_{1}, N_{2}, \ldots \sim \mathcal{N}(m, s) \text { independent, }
\end{aligned}
$$

where:

$\mathcal{N}$ - means normal distribution,

$\mu \quad-$ is the average benefit generated during the year of use,

$\sigma-$ is the standard deviation of the benefits generated during the year of use,

$m$ - is the average amount spent during the year of use,

$s \quad$ - is the standard deviation of expenditures spent during the year of use. 
Notes:

1. In this paper, benefits and expenditures are considered in one year because the research facility has annual, comparable, repeatable cycles of activity.

2. For the above reasons, the assumption of normality of distributions is substantiated. For the studies and analyzes of specific values of benefits and expenditures in the following years, one can test the hypothesis about the normality of distributions and then evaluate their parameters.

3. For the given i-th year of operation the offshore wind turbines $U_{i}$ and $N_{i}$ are correlated and their correlation values are not known.

Distribution of power and environmental expenditures in the use of offshore wind turbines $\left(\mathrm{CO}_{2 \mathrm{eq}}\right.$ emission): Experimental determination of the influence of selected offshore wind farm designs on energy efficiency and benefits was determined by answering the question: what effect on off-shore EW efficiency from $\mathrm{CO}_{2}$ emissions are generated by the use of energy and resources (emissions) of design, manufacture and management?

By dividing the numerator and denominator by $t$ in equation (11), we obtain that

$$
E(t)=\frac{\bar{U}_{t}}{\left(m_{W}+m_{Z}\right) / t+\bar{N}_{t}}
$$

where:

$$
\bar{U}_{t}=\frac{1}{t} \sum_{i=1}^{t} U_{i}, \quad \bar{N}_{t}=\frac{1}{t} \sum_{i=1}^{t} N_{i}
$$

are the average of generated benefits and average generated emissions (spent outlays) per year over the $t$ years of use of offshore EW. The distributions $\bar{U}_{t}$ and $\left(\left(m_{W}+m_{Z}\right) / t+\bar{N}_{t}\right)$ are known:

$$
\begin{aligned}
& \bar{U}_{t} \sim \mathcal{N}(\mu, \sigma / \sqrt{t}), \\
& \left(\left(m_{W}+m_{Z}\right) / t+\bar{N}_{t}\right) \sim \mathcal{N}\left(\left(m_{W}+m_{Z}\right) / t+m, s / \sqrt{t}\right) .
\end{aligned}
$$

Justifying the choice of a normal distribution the consideration was carried out based on Figure 1, a) density $f$, b) the survival function $\bar{F}$ random size $X$ of an average $a$ and standard deviation $d$.
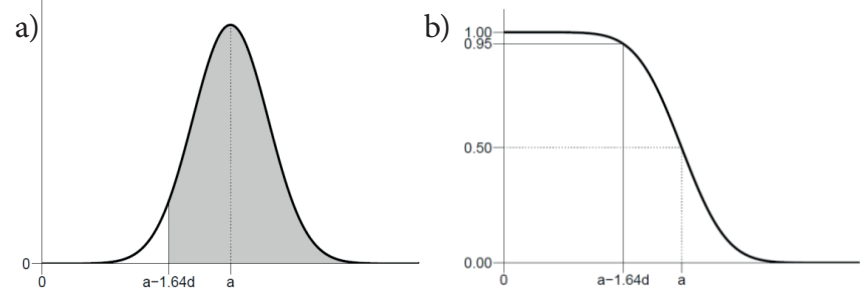

Fig. 1. Density (a) and survival function $(b)$ of the normal distribution for the case in question with parameters $a$ and $d$
To determine the probability that $X$ reaches a value that is equal to or greater than a given value $x$, the field under density is determined/counted on the right of $x$ and the value $\bar{F}$ for $x$ :

$$
\operatorname{Pr}(X \geq x)=\int_{x}^{+\infty} f(x) d x=\bar{F}(x)
$$

In this case, it is characteristic that the normal distribution considered is a "light tail" distribution, i.e. $X$ is reluctant to take values far from the mean $a$. E.g.:

$$
\begin{aligned}
& \operatorname{Pr}(X \geq a-0,67 d)=0,75, \\
& \operatorname{Pr}(X \geq a-1,28 d)=0,9, \\
& \operatorname{Pr}(X \geq a-1,64 d)=0,95, \\
& \operatorname{Pr}(a-4,06 d \leq X \leq a+4,06 d)=0,99995 .
\end{aligned}
$$

The considered integrated efficiency index of the test object $E(t)$ is the quotient of two variables with normal distributions. So constructed random value has so called double unoccupied student distribution. This distribution is very complicated and difficult to use. In particular, there is no formal so called expected value $\mathbb{E} E(t)$, which would naturally define the property $E(t)$. Therefore, in this paper, simplification is defined by the range to which $E(t)$ belongs with probability very close to one.

From (16) it has been concluded that:

$\operatorname{Pr}\left(\mu-\frac{4,06 \sigma}{\sqrt{t}} \leq \bar{U}_{t} \leq \mu+\frac{4,06 \sigma}{\sqrt{t}}\right)=0,99995$,

$$
\begin{aligned}
& \operatorname{Pr}\left(m+\frac{m_{W}+m_{Z}}{t}-\frac{4,06 s}{\sqrt{t}} \leq\left(m_{W}+m_{Z}\right) / t+\right. \\
& \left.\bar{N}_{t} \leq m+\frac{m_{W}+m_{Z}}{t}+\frac{4,06 s}{\sqrt{t}}\right)=0,99995 .
\end{aligned}
$$

From inequality

$$
\operatorname{Pr}(A \cap B) \geq P(A)+P(B)-1
$$

it is therefore apparent that the

$\operatorname{Pr}\left(\frac{\mu-\frac{4,06 \sigma}{\sqrt{t}}}{m+\frac{m_{W}+m_{Z}}{t}+\frac{4,06 s}{\sqrt{t}}} \leq E(t) \leq \frac{\mu+\frac{4,06 \sigma}{\sqrt{t}}}{m+\frac{m_{W^{+} m_{Z}}}{t}-\frac{4,06 s}{\sqrt{t}}}\right) \geq 0,9999$.

So if $\sigma$ is much smaller than $\mu$, and $s$ is much smaller than $m+\left(m_{W}+m_{Z}\right) / t$, then with probability very close one, it can be written approximately that the integrated efficiency index of the test object is:

$$
E(t) \approx \frac{\mu}{m+\frac{m_{W}+m_{Z}}{t}}=\frac{\mu \cdot t}{m_{W}+m \cdot t+m_{Z}}
$$




\section{CASE STUDY}

The integrated efficiency index of the offshore EW expenditure defined as electricity production efficiency from greenhouse gas emissions: a $2 \mathrm{MW}$ wind turbine, a $90 \mathrm{~m}$ blade diameter, installed on a $105 \mathrm{~m}$ tower at a location for the integrated efficiency sea location. An integrated indicator of the efficiency of electricity production from $\mathrm{CO}_{2 \mathrm{eq}}$ emissions was defined. On the basis of the previously presented dependency, the integrated index of the efficiency of the production of electricity from $\mathrm{CO}_{2 \mathrm{eq}}$ emissions can be written as:

$$
E(t)=\frac{U}{m_{W}+m_{U}+m_{Z}} \approx \frac{\mu \cdot t}{m_{W}+m \cdot t+m_{Z}}
$$

where:

$t \quad$ - usage time in years,

$E(t)$ - integrated efficiency index for $t$ years of use,

$U$ - energy produced at the stage of use,

$\mu \quad$ - average annual energy output at the stage of use,

$m_{W}-\mathrm{CO}_{2 \mathrm{eq}}$ emission at the manufacturing stage,

$m_{U}-\mathrm{CO}_{2 \mathrm{eq}}$ emission at the stage of use,

$m$ - average annual $\mathrm{CO}_{2 \mathrm{eq}}$ emissions at the stage of use,

$m_{Z}-\mathrm{CO}_{2 \mathrm{eq}}$ emission at the post use management stage.

The wind farm researched was started in 2012. The average annual production in the long run was determined on the basis of three years of production. $\mathrm{CO}_{2 \mathrm{eq}}$ emissions in the life cycle were determined using the LCA method using CML modeling. For this purpose SimaPro 7.1 software was used. The results of the study were based on criteria designed to develop the mathematical model of energy efficiency of offshore wind farms and to determine the impact of selected wind farm development methods on useful energy benefits and integrated $\mathrm{CO}_{2}$ emissions.

The obtained results of the model variables of the integrated ecological efficiency model $\mathrm{CO}_{2 \mathrm{eq}}$ are presented in Table 1.

Tab. 1. Production of energy during use and $\mathrm{CO}_{2 e q}$ emissions in the life cycle of an offshore wind power plant (source: own research)

\begin{tabular}{|c|l|c|c|c|}
\hline No. & \multicolumn{1}{|c|}{ Indicator } & Symbol & Unit & Value \\
\hline 1. & $\begin{array}{l}\text { Average annual energy output } \\
\text { at the stage of use, }\end{array}$ & $\mu$ & $\mathrm{MWh} \cdot \mathrm{rok}^{-1}$ & 5118 \\
\hline 2. & $\begin{array}{l}\mathrm{CO}_{2 \mathrm{eq}} \text { emission at the } \\
\text { manufacturing stage }\end{array}$ & $m_{W}$ & $\mathrm{Mg} \mathrm{CO}_{2 \mathrm{eq}}$ & 2700 \\
\hline 3. & $\begin{array}{l}\text { Average annual } \mathrm{CO}_{2 \mathrm{eq}} \text { emission } \\
\text { at the stage of use }\end{array}$ & $m$ & $\begin{array}{c}\mathrm{Mg} \\
\mathrm{CO}_{2 \mathrm{eq}} \cdot \mathrm{rok}^{-1}\end{array}$ & 24 \\
\hline 4. & $\begin{array}{l}\mathrm{CO}_{2 \mathrm{eq}} \text { emission at the post use } \\
\text { management stage (storage) }\end{array}$ & $m_{Z}^{S}$ & $\mathrm{Mg} \mathrm{CO}_{2 \mathrm{eq}}$ & 1150 \\
\hline 5. & $\begin{array}{l}\mathrm{CO}_{2 \mathrm{eq}} \text { emission at the post use } \\
\text { management stage (recycling) }\end{array}$ & $m_{Z}^{R}$ & $\mathrm{Mg} \mathrm{CO}_{2 \mathrm{eq}}$ & -704 \\
\hline
\end{tabular}

On this basis, an integrated ecological efficiency of $\mathrm{CO}_{2 \mathrm{eq}}$ emissions was established for the 25-year cycle of use with the production and end-use of $E^{S}(25)$ and $E^{R}(25)$ recycling. The results are presented in Table 2. It also includes the comparison of the values of the integrated ecological efficiency of conventional power plants with $\mathrm{CO}_{2 \mathrm{eq}}$ emissions for [10, 19-23]:
- hard coal,

- brown coal,

- heating oil,

- natural gas.

The combined environmental efficiency of an off-shore wind power plant with $\mathrm{CO}_{2 \mathrm{eq}}$ emissions compared to a conventional coal-fired power plant in an estimated 25-year operating life with potable landfill disposal is 9.93 times higher. However, when managed through recycling - 16.8 times higher.

Tab. 2. Integrated ecological efficiency of offshore EW and conventional power plants with $\mathrm{CO}_{2}$ emissions in a 25-year lifecycle with different ways of managing the offshore wind potential of a wind farm (source: own research)

\begin{tabular}{|c|c|c|c|c|}
\hline No. & Indicator & Symbol & Unit & Value \\
\hline 1. & $\begin{array}{l}\text { Integrated ecological } \\
\text { efficiency of off-shore } \\
\text { EW with } \mathrm{CO}_{2 \mathrm{eq}} \text { emission } \\
\text { (storage) }\end{array}$ & $E^{S}(25)$ & $\mathrm{MWh} \cdot \mathrm{Mg} \mathrm{CO} \mathrm{C}_{2 \mathrm{eq}}$ & 29,38 \\
\hline 2. & $\begin{array}{l}\text { Integrated ecological } \\
\text { efficiency of off-shore } \\
\text { EW with } \mathrm{CO}_{2 \mathrm{eq}} \text { emission } \\
\text { (recycling) }\end{array}$ & $E^{R}(25)$ & $\mathrm{MWh} \cdot \mathrm{Mg} \mathrm{CO} \mathrm{C}_{2 \mathrm{q}}$ & 49,73 \\
\hline 3. & $\begin{array}{l}\text { Integrated ecological } \\
\text { efficiency of } \mathrm{CO}_{2 \mathrm{eq}} \text { emission } \\
\text { for the production of } \\
\text { electricity from fossil fuels } \\
\text { (hard coal) }\end{array}$ & - & $\mathrm{MWh} \cdot \mathrm{Mg} \mathrm{CO} \mathrm{Ceq}$ & $2,96^{*}$ \\
\hline 4. & $\begin{array}{l}\text { Integrated ecological } \\
\text { efficiency of } \mathrm{CO}_{2 \mathrm{eq}} \text { emission } \\
\text { for the production of } \\
\text { electricity from fossil fuels } \\
\text { (brown coal) }\end{array}$ & - & $\mathrm{MWh} \cdot \mathrm{Mg} \mathrm{CO} \mathrm{Cl}_{2 \mathrm{q}}$ & $2,75^{*}$ \\
\hline 5. & $\begin{array}{l}\text { Integrated ecological } \\
\text { efficiency of } \mathrm{CO}_{2 \mathrm{qq}} \text { emission } \\
\text { for the production of } \\
\text { electricity from fossil fuels } \\
\text { (heating oil) }\end{array}$ & - & $\mathrm{MWh} \cdot \mathrm{Mg} \mathrm{CO} \mathrm{CO}_{2 \mathrm{q}}$ & $3,61^{\star}$ \\
\hline 6. & $\begin{array}{l}\text { Integrated ecological } \\
\text { efficiency of } \mathrm{CO}_{2 \mathrm{eq}} \text { emission } \\
\text { for the production of } \\
\text { electricity from fossil fuels } \\
\text { (natural gas) }\end{array}$ & - & $\mathrm{MWh} \cdot \mathrm{Mg} \mathrm{CO} \mathrm{C}_{2 \mathrm{eq}}$ & $4,96^{*}$ \\
\hline
\end{tabular}

* calculated on the basis of data [10]

Integrated off-shore wind power plant efficiency with $\mathrm{CO}_{2 \mathrm{eq}}$ emissions compared to a conventional lignite-fired power plant in an estimated 25-year operating life with a potential utilization of storage capacity is 10.68 times higher. On the other hand, utilization by recycling - 18.08 times higher.

The values of the integrated environmental efficiency of offshore wind power installation with $\mathrm{CO}_{2 \mathrm{eq}}$ emissions in comparison with a conventional power plant utilizing oil or natural gas attain slightly lower values.

A comparison of these data shows the high possibility of reducing $\mathrm{CO}_{2 \mathrm{eq}}$ emissions by designing, manufacturing and using off-shore wind power plants, replacing fossil fuel energy from offshore wind power.

As the integrated ecological efficiency of $\mathrm{CO}_{2 \mathrm{eq}}$ emissions in the life cycle largely depends on the length of the operation phase. Figure 3 illustrates this dependence on the offshore wind farm, taking into account storage and recycling at the 
post-disposal stage, and uncertainty resulting from a forecast of productivity and consumption of energy and materials in use.

Figure 3 also shows the effectiveness of $\mathrm{CO}_{2 \mathrm{eq}}$ emissions for the production of electricity from hard coal and natural gas (2.90 for hard coal, 4.96 for natural gas respectively).

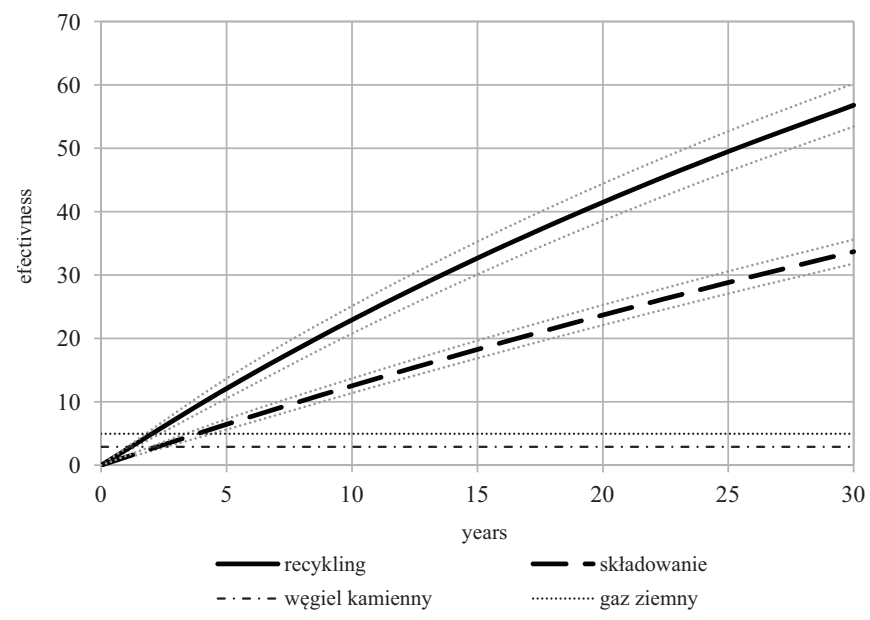

Fig. 2. The dependence of the integrated $\mathrm{CO}_{2 e q}$ efficiency index on the use of different off-shore wind power plants for the various post-shore utilization patterns of the parameters listed in Table 1 (source: own research)

The increasing value of the integrated efficiency index from $\mathrm{CO}_{2 \mathrm{eq}}$ emissions as a function of the time of use for various off-shore utilization patterns of the analyzed off-shore wind turbine of $\mu=5118 \mathrm{MWh} \cdot$ year $^{-1}$ indicates the growing operational potential of offshore wind turbines, even over 25 years of use.

The equations of the lines shown in Figure 2 are mathematically described in Table 3. The values of the integrated energy efficiency index from $\mathrm{CO}_{2 \mathrm{eq}}$ emission are given for the analyzed, rated offshore wind turbine as average, minimum and maximum values for recycling and post-use management.

Tab 3. Integrated $\mathrm{CO}_{2 e q}$ efficiency index for recycling and storage at offshore wind power plants (Source: own research)

\begin{tabular}{|l|l|c|}
\hline No. & \multicolumn{1}{|c|}{ Model } & Mathematical form \\
\hline 1. & recycling & $E^{R}(t)=\frac{5118\left[\frac{M W h}{r o k}\right] \cdot t}{2700[M g]+24\left[\frac{M g}{r o k}\right] \cdot t-704[M g]}$ \\
\hline 2. & storage & $E^{S}(t)=\frac{5118\left[\frac{M W h}{r o k}\right] \cdot t}{2700[M g]+24\left[\frac{M g}{r o k}\right] \cdot t+1150[M g]}$ \\
\hline 3. & recycling $(\max )$ & $E^{R \max }(t)=\frac{5118\left[\frac{M W h}{\text { rok }}\right] \cdot t+1440\left[\frac{M W h}{\sqrt{r o k}}\right] \cdot \sqrt{t}}{2700[M g]+24\left[\frac{M g}{r o k}\right] \cdot t-704[M g]-4\left[\frac{M W h}{\sqrt{r o k}}\right] \cdot \sqrt{t}}$ \\
\hline 4. & recycling $(\min )$ & $E^{R \min }(t)=\frac{5118\left[\frac{M W h}{r o k}\right] \cdot t-1440\left[\frac{M W h}{\sqrt{r o k}}\right] \cdot \sqrt{t}}{2700[M g]+24\left[\frac{M g}{\text { rok }}\right] \cdot t-704[M g]+4\left[\frac{M W h}{\sqrt{r o k}}\right] \cdot \sqrt{t}}$ \\
\hline 5. & storage $(\max )$ & $E^{S \max }(t)=\frac{5118\left[\frac{M W h}{r o k}\right] \cdot t+1440\left[\frac{M W h}{\sqrt{r o k}}\right] \cdot \sqrt{t}}{2700[M g]+24\left[\frac{M g}{r o k}\right] \cdot t+1150[M g]-4\left[\frac{M W h}{\sqrt{r o k}}\right] \cdot \sqrt{t}}$ \\
\hline
\end{tabular}

\begin{tabular}{|c|c|c|}
\hline No. & Model & Mathematical form \\
\hline 6. & storage (min) & $E^{S \sin }(t)=\frac{5118\left[\frac{M W h}{\text { rok }}\right] \cdot t-1440\left[\frac{M W h}{\sqrt{r o k}}\right] \cdot \sqrt{t}}{2700[M g]+24\left[\frac{M g}{\text { rok }}\right] \cdot t+1150[M g]+4\left[\frac{M W h}{\sqrt{r o k}}\right] \cdot \sqrt{t}}$ \\
\hline
\end{tabular}

The installation of a wind power plant also has a significant impact on the integrated ecological efficiency of $\mathrm{CO}_{2 \mathrm{eq}}$ emissions in the life cycle, and thus the average annual energy output. Figure 3 illustrates this relationship for the various post-use uses and duration of use. The effectiveness of $\mathrm{CO}_{2 \mathrm{e}}$ emissions for the production of electricity from hard coal and natural gas has also been emphasized.

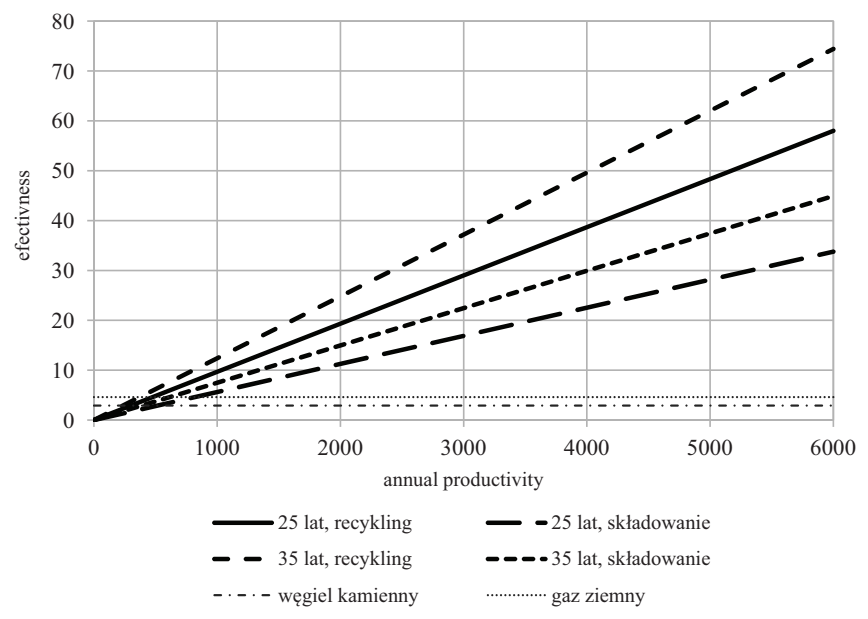

Fig. 3. Dependency of integrated CO2eq efficiency index from average annual productivity of the offshore wind farm analyzed for different lengths of use and management (source: own research)

The equations of the lines shown in Figure 3 have the mathematical form as described in Table 4.

Tab. 4. Integrated $\mathrm{CO}_{2 e q}$ efficiency index for recycling and storage at offshore development, for 25 and 35 years of operation (source: own research)

\begin{tabular}{|c|c|c|}
\hline Lp. & Model & Mathematical form \\
\hline 1. & 25 years, recycling & $E^{R}(25)(\mu)=\frac{25[\text { lat }] \cdot \mu}{2700[\mathrm{Mg}]+25[\text { lat }] \cdot 24\left[\frac{\mathrm{Mg}}{\mathrm{rok}}\right]-704[\mathrm{Mg}]}$ \\
\hline 2. & 25 years, storage & $E^{S}(25)(\mu)=\frac{25[\mathrm{lat}] \cdot \mu}{2700[\mathrm{Mg}]+25[\text { lat }] \cdot 24\left[\frac{\mathrm{Mg}}{\mathrm{rok}}\right]+1150[\mathrm{Mg}]}$ \\
\hline 3. & 35 years, recycling & $E^{R}(35)(\mu)=\frac{35[\text { lat }] \cdot \mu}{2700[\mathrm{Mg}]+35[\text { lat }] \cdot 24\left[\frac{\mathrm{Mg}}{\mathrm{rok}}\right]-704[\mathrm{Mg}]}$ \\
\hline 4. & 35 years, storage & $E^{S}(35)(\mu)=\frac{35[\text { lat }] \cdot \mu}{2700[\mathrm{Mg}]+35[\text { lat }] \cdot 24\left[\frac{\mathrm{Mg}}{\mathrm{rok}}\right]+1150[\mathrm{Mg}]}$ \\
\hline
\end{tabular}

\section{SUMMARY AND CONCLUSIONS}

In the light of the assumptions, results of research and accompanying calculations, analytical and research work was carried out to solve the problems formulated to achieve the objectives of the article by: 
1. the solution of the first problem is the development of an adequate mathematical model for the efficiency of electricity production from $\mathrm{CO}_{2}$ emissions for the purposes of analysis, evaluation and development of marine EW. The model incorporates variable indicators, supporting the design, manufacture, use and management of post-use potentials.

2. the solution to the second problem is to determine the experimental impact of the selected management, use and location, i.e. the average annual productivity of offshore wind power plants, on the energy benefits of $\mathrm{CO}_{2}$ emissions. It was found that the efficiency of electricity production from $\mathrm{CO}_{2}$ emission is influenced by the following factors occurring in the offshore EW:

a) methods of post-use management;

For two ways of managing post-use management (storage, recycling), the more favorable values of the efficiency index were obtained for recycling. Using the recycling for the tested EW and its useful life for 25 years, the $\mathrm{CO}_{2 \mathrm{eq}}$ energy efficiency index is $E^{R}(25)=49,73$, and using storage $E^{S}(25)=29,38$

The EW offshore efficiency rating for $\mathrm{CO}_{2 \mathrm{eq}}$ compared to the conventional coal-fired power plant in the estimated 25 -year lifetime for storage capacity is 9.93 times higher (Table 2). On the other hand, in management by recycling 16.8 times higher. For lignite, these values are: 10,68 times when stored, recycled - 18.08 times.

b) Operating time;

The values of the integrated energy efficiency index from $\mathrm{CO}_{2 \mathrm{eq}}$ emissions as a function of the time of use for the different utilization patterns of the analyzed offshore wind power plant with an average annual production of energy $\mu=5118$ indicate the increasing operational potential of offshore wind power plants, along with the increasing lifetime. For the period of use of 25 years, these indices are respectively $E^{S}(25)=29,38$, $E^{R}(25)=49,73$, and for long service life of up to 35 years $E^{S}(35)=38,31$ and $E^{R}(35)=63,48$.

c) Location - average annual productivity;

Choosing a location is crucial for achieving high electricity production from $\mathrm{CO}_{2 \mathrm{eq}}$ emissions. For comparison, if we assume that the operating life is 25 years, these rates, with a fluctuation in annual productivity around $\mu=5118$ by 5118 by $\pm 10 \%$, are respectively:

$$
\begin{aligned}
& E^{S}(25)(90 \% \mu)=25,94, E^{S}(25)(110 \% \mu)=31,70, \\
& E^{R}(25)(90 \% \mu)=44,53, E^{R}(25)(110 \% \mu)=54,43 .
\end{aligned}
$$

Compared to the results obtained, there is considerable potential for reducing $\mathrm{CO}_{2 \mathrm{eq}}$ emissions from the design, manufacture and operation of offshore wind farms, replacing fossil fuel energy with offshore wind power.

\section{LITERATURE}

1. Alberts H. Recycling of wind turbine rotor blades - fact or fiction? Dewi Magazin 2009; 2(34): 32-41.

2. Conconi M. Raport EWEA: Research note outline on recycling wind turbines blades. Brussels: The European Wind Energy Association, 2012.

3. Davidsson J, Hook M, Wall G. Review of life cycle assessments on wind energy systems. The International Journal of Life Cycle Assessment 2012; 17(6): 729-742.

4. Davis S, Peters G P, Calderia K. The supply chain of $\mathrm{CO}_{2}$ emissions. Proceedings of the National Academy of Sciences 2011; 108(45): 18554-18559.

5. Flizikowski J, Sadkiewicz J, Tomporowski A. Charakterystyki użytkowe sześciowalcowego mielenia uziarnionych surowców dla przemysłu chemicznego i spożywczego. Przemysł chemiczny 2015; 94(1): 69-75.

6. Flizikowski J, Topoliński T, Opielak M, Tomporowski A, Mroziński A. Research and Analysis of Operating Characteristics of Energetic Biomass Micronizer. Eksploatacja i Niezawodnosc - Maintenance and Reliability 2015; 17(1): 19-26.

7. Garrett P, Rendc K. Life cycle assessment of wind power: comprehensive results from a state-of-the-art approach. The International Journal of Life Cycle Assessment 2013; 18(1): 37-48.

8. Gilingham K, Newell R, Palmer K. Energy efficiency, economics and policy. Annual Review of Resource Economics 2009; 1(1): 597-620.

9. Hau E. Wind turbines: Fundamentals, technologies, application and economics. Berlin: Springler-Verlag, 2006.

10. Kasner R. Ocena korzyści i nakładów cyklu życia elektrowni wiatrowej. Dysertacja. Poznań: Politechnika Poznańska, 2016.

11. Kłos Z, Małdziński L, Wisłocki K. Rozprawy naukowe. Poznań: Wydawnictwo Politechniki Poznańskiej, 2011.

12. Kosicka E, Kozłowski E, Mazurkiewicz D. The use of stationary tests for analysis of monitored residual processes. Eksploatacja i Niezawodnosc - Maintenance and Reliability 2015; 17(4): 604-609.

13. Malujda I. Kierunki projektowania i badania cech konstrukcyjnych elementów maszyn. Poznań: Wydawnictwo Politechniki Poznańskiej, 2006. 
14. Mitchell R B. Technology is not Enough: Climate change, population, affluence and consumption. Journal of Environment \& Development 2012; 21(1): 24-27.

15. Oexmann J. Post-combustion $\mathrm{CO}_{2}$ capture: energetic evaluation of chemical absorption processes in coal-fired steam power plants. Hamburg: Epubli, 2011.

16. Petrakopoulou F, Tsatsaronis G, Morosuk T, Paitazoglou C. Environmental evaluation of a power plant using conventional and advamced exergy-based mathods. Energy 2012; 45(1): 23-30.

17. Piasecka I. Badanie i ocena cyklu życia zespołów elektrowni wiatrowych. Dysertacja. Poznań: Politechnika Poznańska, 2014.

18. Piasecka I. Charakterystyki destrukcyjności KujawskoPomorskich elektrowni wiatrowych. Rozdział w monografii: V Eko-Euro-Energia. Inżynieria Odnawialnych Źródeł Energii pod red. A. Mrozińskiego. Bydgoszcz: Wydawnictwo Fundacji Rozwoju Mechatroniki, 2013.

19. PN-EN ISO 14040:1997. Zarządzanie środowiskowe Ocena cyklu życia - Zasady i struktura. Warszawa: PKN, 2000.

20. PN-EN ISO 14041:1998. Zarządzanie środowiskowe Ocena cyklu życia - Określenie celu i zakresu oraz analiza zbioru. Warszawa: PKN, 2002.

21. PN-EN ISO 14042:2000. Zarządzanie środowiskowe Ocena cyklu życia - Ocena wpływu cyklu życia. Warszawa: PKN, 2002.

22. PN-EN ISO 14043:2000. Zarządzanie środowiskowe Ocena cyklu życia - Interpretacja cyklu życia. Warszawa: PKN, 2002.

23. Popczyk J. Bezpieczeństwo elektroenergetyczne w społeczeństwie postprzemysłowym na przykładzie Polski. Gliwice: Wydawnictwa Politechniki Śląskiej, 2009.

24. Popczyk J. Energetyka rozproszona - od dominacji energetyki w gospodarce do zrównoważonego rozwoju, od paliw kopalnych do energetyki odnawialnej i efektywności energetycznej. Warszawa: Polski Klub Ekologiczny Okręg Mazowiecki, 2011.

25. Price T J. UK large-scale wind power programme from 1970 to 1990: The carmarthen bay experiments and the musgrove vertical-axis turbines. Wind Engineering 2006; 30(3): 225-242.

26. Raupach M, Marland G, Ciais P, Canadell J. Global and regional drivers of accelerating $\mathrm{CO}_{2}$ emissions. Proceedings of the National Academy of Sciences 2007; 104(24): 10288-10293.

27. Rijswijk K, Bersee H E N. Reactive processing of textile fiber-reinforced thermoplastic composites - An overview. Composite Part A: applied science and manufacturing 2007; 38(3): 666-681.

28. Rudnicki J. Application isssues of the semi-markov reliability model, Polish Maritime Research 1(85) 2015, 22:55-64, 10.1515/pomr-2015- 000

29. Tomporowski A, Opielak M. Structural features versus multi-hole grinding efficiency. Eksploatacja i Niezawodność - Maintenance and Reliability 2012; 14(3): 223-228.

30. Tomporowski A. Stream of efficiency of rice grains multidisc grinding. Eksploatacja i Niezawodnosc - Maintenance and Reliability 2012; 14(2): 150-153.

31. Ulgiati S, Raugei M, Bargigli S. Overcoming the in adequacy of single-criterion approaches to Life Cycle Assessment. Ecological Modelling 2006; 190(3-4): 432-442.

32. Wang D, Bao A, Kunc W, Liss W. Coal power plant flue gas waste heat and water recovery, Applied Energy 2012; 91(1): 341-348.

33. WnukZ. Ekologia i ochrona środowiska. Wybrane zagadnienia. Rzeszów: Wydawnictwo Uniwersytetu Rzeszowskiego, 2010.

34. Zimmermann T. Parameterized tool for site specific LCAs of wind energy converters. The International Journal of Life Cycle Assessment 2013; 18(1): 49-60. 


\section{CONTACT WITH THE AUTHORS}

\section{Andrzej Tomporowski}

e-mail:a.tomporowski1@wp.pl

Uniwersytet Technologiczno-Przyrodniczy

im. J. i J. Śniadeckich w Bydgoszczy

S. Kaliskiego 7,

85-796 Bydgoszcz

Poland

\section{Józef Flizikowski}

e-mail:fliz@utp.edu.pl

Uniwersytet Technologiczno-Przyrodniczy im. J. i J. Śniadeckich w Bydgoszczy

S. Kaliskiego 7

85-796 Bydgoszcz

Poland

\section{Marek Opielak}

e-mail:m.opielak@pollub.pl

Politechnika Lubelska

Nadbystrzycka 36

20-610 Lublin

Poland

\section{Robert Kasner}

e-mail:robert.kasner@gmail.com

Uniwersytet Technologiczno-Przyrodniczy im. J. i J. Śniadeckich w Bydgoszczy

S. Kaliskiego 7

85-796 Bydgoszcz

Poland

\section{Weronika Kruszelnicka}

e-mail: weronika.kruszelnicka@gmail.com Uniwersytet Technologiczno-Przyrodniczy im. J. i J. Śniadeckich w Bydgoszczy

S. Kaliskiego 7

85-796 Bydgoszcz

Poland 